\title{
PENGUATAN PENDIDIKAN KARAKTER DALAM PEMBELAJARAN MATEMATIKA DENGAN MENGGUNAKAN MOTIF KAIN TENUN INSANA
}

\section{STRENGTHENING OF CHARACTER EDUCATION IN MATHEMATICS LEARNING USING INSANA MOTIF OF WOVEN FABRIC}

\author{
${ }^{1)}$ Stanislaus Amsikan, ${ }^{2)}$ Yohanis Ndapa Deda \\ ${ }^{1,2)}$ Pendidikan Matematika Universitas Timor \\ Email: yndapadeda@unimor.ac.id
}

\begin{abstract}
ABSTRAK
Lingkungan dan budaya sangat berperan dalam membentuk karakter anak karena waktu yang dimiliki anak tidak hanya di Sekolah tetapi juga di lingkungan keluarga. Pemerintah telah memasukkan pendidikan karakter dalam kurikulum 2013 dan telah direvisi tahun 2017 yang berbasis kompetensi dan karakter. Namun guru sekolah dasar masih kesulitan mengimplementasikannya dalam pembelajaran matematika. Untuk mencapai tujuan pendidikan nasional secara optimal, maka salah satu cara yang kami tawarkan kepada guru adalah Menggunakan Motif Kain Tenun Insana dalam Pembelajaran Matematika untuk penguatan pendidikan karakter, mencintai subnilai nasionalis, yaitu apresiasi budaya bangsa sendiri. Tujuan kegiatan ini adalah untuk meningkatkan kreativitas guru Sekolah Dasar dalam mengimplementasikan Penguatan Pendidikan Karakter (PPK) Melalui Pembelajaran Matematika dengan Menggunakan Motif Kain Tenun Insana di SDN Kenari. Metode yang digunakan dalam menganalisis data adalah deskriptif kualitatif. Hasil pengabdian menunjukkan bahwa guru sekolah dasar di SDN Kenari mengalami peningkatan kreatifitas dalam mengimplementasikan PPK melalui pembelajaran matematika dengan menggunakan motif kain tenun Insana. Hal ini dapat dilihat dari hasil pretest $65 \%$ menjadi $81 \%$ pada posttest.
\end{abstract}

Kata kunci: Pendidikan Karakter; Pembelajaran Matematika; Motif Kain Tenun Insana

ABSTRACT

The environment and culture are instrumental in shaping the child's character because of the time that the child is not only in school but also in the family environment. Indonesian government has incorporated the character education in the 2013 curriculum and has revised the 2017 which based on competence and character. Therefore elementary school teachers are still struggling to implement mathematics learning. To achieve the objective of national education optimally, then one of the way that we offer teachers is to use the Insana motif of woven fabric in mathematics learning to strengthen character education, love the nationalist sub-values, namely cultural appreciation of the nation itself. The purpose of this dedication is to increase the creativity of elementary school teachers in implementing the strengthening of character education (PPK) through mathematics learning by using the Insana motif of woven fabric at SDN Kenari. The method used in analyzing data is qualitative descriptive. The results showed that elementary school teachers at SDN Kenari experienced a creativity increase in implementing PPK through mathematical learning by using the Insana motif of woven fabric. It can be seen from the results of pretests $65 \%$ to $81 \%$ in posttest.

Keywords: Character Education; Mathematics Learning; Insana Motif of Woven Fabric

Submitted : 21 Januari 2019 Revision : 1 Oktober 2019 Accepted : 17 Februari 2020 


\section{PENDAHULUAN}

Degradasi moral, etika, dan budi pekerti yang kian merosot seiring dengan perkembangan jaman. Hal ini dapat di lihat dari pemberitaan media televisi, radio, dan internet bahwa ada siswa sekolah dasar yang memenjarakan gurunya sendiri. Selain itu masalah pembangunan Sumber Daya Manusia (SDM) harus dimulai dari SD karena disinilah dasar berdirinya berbagai pengetahuan yang sangat berguna bagi pembangunan diri, keluarga, masyarakat, dan bangsa. Karena betapa pentingnya penguatan pendidikan karakter (PPK), sehingga Presiden Joko Widodo menerbitkan Perpres Nomor 87 Tahun 2017 tentang Penguatan Pendidikan Karakter.

Gerakan pendidikan di sekolah untuk memperkuat karakter siswa melalui harmonisasi olah hati (etik), olah rasa (estetik), olah pikir (literasi), dan olah raga (kinestetik) dengan dukungan pelibatan publik dan kerja sama antara sekolah, keluarga, dan masyarakat yang merupakan bagian dari Gerakan Nasional Revolusi Mental (GNRM). Penyelenggaraan PPK pada Satuan Pendidikan jalur Pendidikan Formal merupakan tanggungjawab kepala sekolah dan guru. Penguatan nilai-nilai karakter dapat dilakukan melalui kegiatan penguatan materi pembelajaran, metode pembelajaran sesuai dengan muatan kurikulum 2013 revisi 2017.

Permasalahan yang terjadi di SDN Kenari adalah masih banyak guru yang belum paham implementasi K-13. Secara khusus pada salah satu nilai utama yaitu Nasionalis. Nilai karakter nasionalis merupakan cara berpikir, bersikap, dan berbuat yang menunjukkan kesetiaan, kepedulian, dan penghargaan yang tinggi terhadap bahasa, lingkungan fisik, sosial, budaya, ekonomi,dan politik bangsa, menempatkan kepentingan bangsa dan negara di atas kepentingan diri dan kelompoknya. Subnilai nasionalis antara lain apresiasi budaya bangsa sendiri, menjaga kekayaan budaya bangsa,rela berkorban, unggul, danberprestasi, cinta tanah air, menjaga lingkungan,taat hukum, disiplin,menghormati keragaman budaya, suku, dan agama. Salah satu cara terbaik mengapresiasi dan menjaga budaya bangsa adalah dengan menggunakan prinsip kearifan lokal. Kearifan lokal yang kami maksud disini adalah Motif Kain Tenun Insana.
Sejak diberlakukan K-13 Revisi 2017, guru hanya menyanyikan lagu Indonesia raya dan lagu-lagu nasional lainnya sebagai pembiasaan untuk menumbuhkan karakter Nasionalis. Guru tidak kreatif dan ketidaktahuan guru akan kearifan lokal yang dapat digunakan sebagai sumber belajar yang inovatif dalam melaksanakan kegiatan belajar mengajar di kelas adalah salah satu penyebab sehingga guru-guru di SDN Kenari belum bisa mengintegrasikan Nilai karakter nasionalis ke dalam kegiatan inti proses pembelajaran. Berdasarkan kondisi yang dialami guru-guru SDN Kenari, maka melalui kegiatan pengabdian ini, Guru-guru SDN Kenari sebagai sekolah mitra dan Tim ingin melakukan workshop Integrasi Penguatan Pendidikan Karakter Melalui Pembelajaran Matematika dengan Menggunakan Motif Kain Tenun Insana bagi Guru SD di Kelurahan Kefamenanu Tengah sebagai solusi dari permasalahan tersebut.

Pendidikan karakter adalah suatu sistem penamaan nilai-nilai karakter yang meliputi komponen pengetahuan, kesadaran atau kemauan, dan tindakan untuk melaksanakan nilai-nilai tersebut, baik terhadap Tuhan Yang Maha Esa, diri sendiri, sesama, lingkungan, maupun kebangsaan. Pengembangan karakter dapat dilakukan melalui pengembangan karakter individu seseorang. Karakter harus dibangun dan dikembangkan secara sadar hari demi hari dengan melalui suatu proses (Haryati, 2013). Pendidikan karakter merupakan hal yang sangat penting dan menjadi kebutuhan untuk saat ini mengingat relasi-relasi antar manusia mengalami degradasi karakter (Setiawan, 2011). selain terjadi penurunan karakter bangsa, budaya dan bahasa luar juga sudah diajarkan di sebagian sekolah, seperti pengenalan bahasa dan budaya Jepang (Kartika, dkk, 2017).

Beberapa hasil penelitian terkait integrasi PPK dalam pembelajaran, Nilai-nilai karakter yang diintegrasikan ke dalam Pembelajaran Kewarganegaraan di Sekolah Dasar, yaitu: (1) Peduli sosial, cerdas, cinta tanah air, demokratis, disiplin, jujur, kerja keras, menghargai prestasi, peduli lingkungan, rasa ingin tahu, semangat kebangsaan, tanggung jawab, dan toleransi; (2) Pengintegrasian nilai karakter kedalam 
perangkat pembelajaran Kewarganegaraan SD dilakukan dengan cara memahami substansi SK dan KD. Memahami konsep dan perilaku yang diharapkan di dalam SK dan KD menjadi kunci dalam penyusunan indikator. Dari indikator tersebut akan menjadi acuan dalam menyusun alat evaluasi dan materi ajar. Dari materi ajar akan memandu dalam memilih metode pembelajaran. Dalam upaya mengembangkan nilai-nilai karakter melalui pembelajaran, SDN Indrasari 1 Martapura telah melakukan pengorganisasian kelas secara baik. Dalam melaksanakan proses pembelajaran, guru menggunakan pendekatan saintitif, dimana siswa dilibatkan dalam proses pembelajaran melalui pengamatan, menanya, mencoba, menalar, dan mengkomunikasikan. Penilaian yang dilakukan oleh guru mengacu kepada empat kompetensi inti yaitu aspek spiritual, sikap sosial, pengetahuan dan keterampilan. Dalam melaksanakan proses pembelajaran tersebut, minimal guru bisa mengembangkan nilai karakter religius, tanggung jawab, disiplin, kerjasama, ketelitian, kejujuran dan kesantunan (Adawiah, 2015). Deda dan Disnawati (2017) mengatakan bahwa ada hubungan motif kain tenun masyarakat Suku Dawan di Kabupaten TTU dengan matematika sekolah yang kemudian digunakan sebagai salah satu potensi lokal dalam workshop pembelajaran matematika (Amsikan dan Deda, 2018). Hasil penelitian lebih lanjut tentang motif kain tenun masyarakat Kefamenanu (Deda dan Amsikan, 2019) hanya sebatas mengeksplorasi kaitan antara motif kain tenun dan matematika sekolah, belum sampai pada implementasi ke dalam proses pembelajaran, apalagi integrasi dengan PPK.

Tujuan yang ingin dicapai pada pengabdian ini adalah untuk meningkatkan kreativitas guru SD dalam mengimplementasikan PPK Melalui Pembelajaran Matematika dengan Menggunakan Motif Kain Tenun Insana di SDN Kenari. Luaran yang dinginkan dalam pelaksanaan pengabdian ini adalah Perangkat Pembelajaran berupa RPP dengan Tema Lingkungan.

\section{METODE}

Mitra yang menjadi sasaran dalam kegiatan pengabdian ini adalah guru-guru SDN Kenari yang berjumlah 17 Orang. Tempat pelaksanaan di Aula SDN Kenari Kelurahan Kefamenanu Tengah, Kecamatan Kota Kefamananu, Kabupaten Timor Tengah Utara, Provinsi NTT. Metode yang digunakan dalam pelaksanaan pengabdian ini adalah Pelatihan Praktek dengan mengikuti mekanisme Perencanaan, Pelaksanaan, Evaluasi dan Refleksi (Deda dan Disnawati, 2019).

Tahap pelaksanaan dijelaskan berikut ini :

1. Perencanaan, yaitu melakukan persiapan dengan berkoordinasi dengan sekolah mitra terkait waktu pelaksanaan, menyiapkan alat-alat dan bahan yang dibutuhkan saat pelatihan, melakukan bedah kurikulum K-13 revisi tahun 2017 dengan tujuan untuk mengetahui kompetensi inti dan kompetensi dasar yang sesuai dengan jadwal kegiatan pengabdian mata pelajaran matematika dan motif kain tenun insana.

2. Pelaksanaan, yaitu melaksanakan pelatihan integrasi PPK dalam pembelajaran Matematika menggunakan konteks motif kain tenun di sekolah mitra bertempat di SDN Kenari, melakukan kerja kelompok menggunakan media animasi yang dikerjakan oleh guru mitra. Kemudian tim pengusul bersama guru mitra melakukan evaluasi.

3. Peer Teaching, yaitu salah seorang guru melakukan praktek mengajar kelas kecil di depan peserta workshop dipandu tim pelaksana. Tujuannya untuk melihat hasil kerja kelompok guru mitra. Kemudian dilanjutkan dengan mengajar di kelas besar, dimana beberapa guru dan tim betindak sebagai observer.

4. Evaluasi dan refleksi yang dilakukan secara langsung oleh guru mitra dengan mengisi format evaluasi. Evaluasi terhadap materi, cara penyampaian dan manfaat bagi peserta. Proses evaluasi dilaksanakan untuk mengukur tingkat kreativitas guru dan dalam pelaksanaan kegiatan pengabdian dan menentukan langkah selanjutnya. 


\section{HASIL DAN PEMBAHASAN}

Kegiatan ini dilakukan dengan memberikan pelatihan sebanyak dua kali, yaitu hari pertama pada tanggal 31 Agustus 2018 dan hari kedua 1 September 2018. Sebelum melakukan pelatihan menggunakan motif kain tenun insane, guru mitra diberikan prestest berupa lembar kerja guru (LKG). Di dalam LKG termuat pertanyaan mengenai kompetensi inti, kompetensi dasar, dan indicator yang cocok dengan budaya lokal yang digunakan yaitu motif kain tenun Insana. Rata-rata hasil pretest adalah $65 \%$ guru mitra cukup kreatif dalam membuat indicator yang sesuai dengan konteks motif kain tenun insana. Sedangkan setelah pelatihan hari pertama dan pendampingan pada hari kedua, guru mitra diberikan postets pada akhir pertemuan hari kedua. Hasilnya diperoleh bahwa terjadi peningkatan signifikan kreatifitas guru sebesar $16 \%$. Hal ini dapat dilihat dari rat-rata hasil posttest $81 \%$. Hal ini juga terjadi karena pada saat pendampingan tim pelaksana dibantu oleh dua orang mahasiswa dan satu orang dosen prodi pendidikan matematika yang ahli dibidang pendampingan implementasi Perangkat pembelajaran matematika sekolah dasar dan menengah.

Pelatihan disampaikan oleh Tim pengabdian dimulai dengan tanya jawab tentang pembelajaran mengintegrasikan PPK menggunakan motif kain tenun Insana untuk mengetahui secara umum kebutuhan dan kemampuan awal guru. Para guru $100 \%$ belum menggunakan motif kain tenun insana sebagai salah sumber belajar apalagi dengan tujuan PPK. Dalam pelatihan ini para peserta diajarkan bagaimana menggunakan motif kain tenun Insana dan mengeksplorasi konsep matematika yang termuat dalam kain tenun melalui pengamatan langsung, kemudian membuat perangkat pembelajaran untuk PPK dan digunakan sebagai bahan peer teaching.

Workshop Pengintegrasian Nilai-Nilai karakter dapat dilakukan melalui pengintegrasian secara implisit melalui bahan ajar maupun terintegrasi dalam kegiatan proses pembelajaran (Sukayasa, \& Awuy,2014).

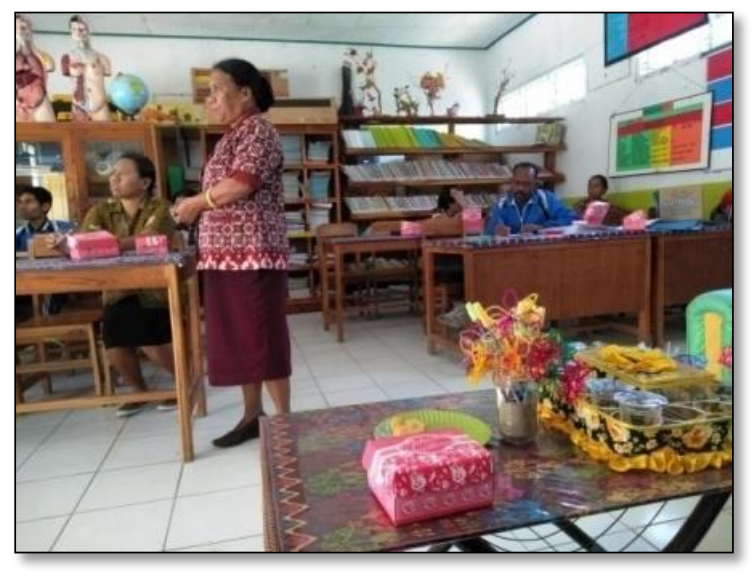

Gambar 1. Foto salah seorang guru Mitra saat persiapan Peer Teaching.

Berdasarkan hasil evaluasi kebutuhan awal mereka, kegiatan pelatihan dimulai dengan penyampaian materi tentang menggunakan motif kain tenun insana sebagai salah sumber belajar untuk tujuan PPK. Kegiatan ini memerlukan waktu yang agak lama kurang lebih 2 jam 30 menit karena peserta belum terbiasa mengintegrasikan PPK dalam pembelajaran matematika. Setelah para peserta memahami bahwa ternyata dalam motif kain tenun ada konsep-konsep matematika seperti segitiga dan segiempat, maka mereka membuat perangkat pembelajaran secara berkelompok.

Pada hari kedua dilanjutkan dengan pendampingan ujicoba perangkat pembelajaran di kelas besar, yaitu kelas IIIa dan IV C.

Setelah pelaksanaan kegiatan, tim menyebar Kuisioner untuk mendapatkan feedback dari guru mitra tentang penggunaan motif kain tenun insana dalam pembelajaran di sekolah dasar. Berdasarkan hasil evaluasi tersebut dapat diketahui beberapa hal sebagai berikut:

1. $35 \%$ peserta sangat setuju, $65 \%$ setuju, bahwa materi sangat relevan dan telah sesuai dengan yang saya harapkan.

2. $37 \%$ peserta sangat setuju, $63 \%$ setuju, bahwa materi terorganisasi dengan baik dan mudah dimengerti.

3. $70 \%$ peserta sangat setuju, $30 \%$ setuju, bahwa keseluruhan diskusi/tanyajawab telah sangat membantu meningkatkan pemahaman peserta.

4. $35 \%$ peserta sangat setuju, $65 \%$ setuju, bahwa kerja praktik dalam kelompok 
adalah efektif untuk menyelesaikan tugas yang diberikan.

Hasil kuesioner yang diberikan dapat disimpulkan bahwa para peserta sangat setuju dan setuju mengenai pelaksanaan dari awal hingga akhir PkM. Selanjutnya para peserta berkeinginan dan berharap adanya kegiatan lanjutan.

Workshop Integrasi PPK menggunakan konteks motif kain tenun Insana bagi Guru Sekolah Dasar telah diikuti 17 orang guru mitra dari SD Negeri Kenari Kelurahan Kefamenanu Tengah Kota Kefamenanu. Kegiatan ini dilaksanakan pada tanggal 31 Agustus -1 September 2018. Pada pelaksanaan guru diminta untuk membuat perangkat Pembelajaran berupa RPP bertema Lingkungan. Setelah pelaksanaan pelatihan ini, setiap guru diminta untuk membuat sendiri RPP.

Berdasarkan konteks budaya lokal yang di kefamenanu. Tim mendampingi pembuatan RPP hingga guru tersebut berhasil menyelesaikan proyek tugas yang diberikan.Pemilihan tema lingkungan bertujuan untuk menanamkan sikap mencintai lingkungan, budaya lokal, motif kain tenun yang di Kabupaten TTU.

Berdasarkan hasil evaluasi, setelah mendapatkan pelatihan selama 2 kali berturutturut para guru sudah mampu membuat sendiri perangkat Pembelajaran berupa RPP bertema Lingkungan menggunakan konteks motif kain tenun (Amsikan \& Deda, 2018). Indikator capaian dari hasil kegiatan pengabdian adalah selain guru mampu memahami penggunaan motif kain tenun insana sebagai media untuk penguatan pendidikan pendidikan karakter (PPK) juga dapat dilihat dari hasil pretest dan postest. Hasil pelatihan dan pendampingan guru sekolah dasar dalam menggunakan motif kain tenun Insana untuk penguatan pendidikan karakter (PPK) sudah sejalan dengan penggunaan konteks motif kain tenun Timor dalam pembelajaran matematika (Deda \& Disnawati, 2019; Disnawati \& Nahak, 2019).

\section{SIMPULAN}

Workshop yang dilakukan dalam dua hari ini telah menunjukkan peningkatan kreatifitas guru Sekolah Dasar dalam pembuatan perangkat Pembelajaran berupa RPP bertema Lingkungan menggunakan konteks motif kain tenun untuk mendukung pembelajaran di kelas. Hal ini dapat dilihat dari hasil pretest $65 \%$ dan postets $81 \%$ kreatifitas guru SD dalam menggunakan motif kain tenun Insana sebagai konteks dalam pembelajalan matematika di kelas.

Direkomendasikan bahwa perlu adanya penelitian pengembangan lebih lanjut tentang Integrasi kearifan lokal yang ada di kawasan perbatasan untuk diintegrasikan ke dalam proses pembelajaran matematika.

\section{DAFTAR PUSTAKA}

Adawiah, R. (2015). Integrasi Pendidikan Karakter Melalui Pembelajaran (Studi Di SDN Indrasari 1 Martapura). Jurnal Vidya Karya, 27 (7).

Amsikan, S. \& Deda, Y.N. (2018). Memanfaatkan Potensi Lokal Kefamenanu Dalam Pembelajsrsn Matematika Untuk Meningkatkan Kreativitas Guru SMP. Bakti Cendana : Jurnal Pengabdian Masyarakat, 1(1)

Deda, N. Y, Amsikan, S. (2019). Geometry Concept On The Motifs Of Woven Fabric In Kefamenanu Community. JRA : Journal of Advances of Mathematics Education, 4(1)

Deda, N. Y, Disnawati, H. (2017). Hubungan Motif Kain Tenun Masyarakat Suku Dawan - Timor Dengan Matematika Sekolah. Prosiding Konferensi Nasional Matematika dan Penelitiannya.18 Maret 2017. Surakarta, Indonesia. p. 201-209.

Deda, Y.N. \& Disnawati, H. (2019). Workshop Media Animasi Untuk Meningkatkan Kreativitas Guru Di Kelurahan Kefamenanu Tengah. Ethos: Jurnal Penelitian dan Pengabdian kepada Masyarakat, 7(1),70-76.

Deda, Y.N. \& Disnawati, H. (2019). Pengembangan Lembar Kerja Matematika (LKM) Etnomatematika 
Menggunakan Konteks Motif Kain Tenun Timor. JKPM: Jurnal Karya Pendidikan Matematika, 6(2): 20-26.

Haryati, S. (2017), Pendidikan Karakter dalam Kurikulum 2013 dalam http://lib. untidar. ac. id/wpcontent/uploads/2017/01/Pendidikan

Disnawati, H. \& Nahak, S. (2019). Pengembangan Lembar Kerja Siswa Berbasis Etnomatematika Tenun Timor pada Materi Pola Bilangan. Jurnal Elemen 5(1), 64-79.

Kartika, D., Astuti,Y., Bakar,Y., \& Mardius,A. (2017). Pengenalan bahasa dan Budaya Jepang bagi Guru dan Siswa. JPPM: Jurnal Pengabdian dan Pemberdayaan Masyarakat, 1(2): 161165.

Setiawan, A.K. (2011)., Integrasi Pendidikan Karakter dalam Pembelajaran Berbasis Interkultural. Jurnal Pendidikan Karakter, 1 (1), 110-118

Sukayasa \& Awuy, E. (2014), Pengintegrasian Nilai-Nilai Kemanusiaan (Human Values) dalam Pembelajaran Tematik Sekolah Dasar, Jurnal Kreatif Tadulako, 17 (2), 54-61 